\title{
Graphene Matrices as Carriers for Metal Ions against Antibiotic Susceptible and Resistant Bacterial Pathogens
}

\author{
Anthony J. Slate ${ }^{1,2}{ }^{4}$, Nathalie Karaky ${ }^{2}$, Grace S. Crowther ${ }^{3}$, Jonathan A. Butler ${ }^{3}$, Craig E. Banks ${ }^{3}{ }^{(D}$, \\ Andrew J. McBain ${ }^{4}(1)$ and Kathryn A. Whitehead ${ }^{2, *}$ \\ 1 Department of Biology and Biochemistry, University of Bath, Claverton Down, Bath BA2 7AY, UK; \\ ajs319@bath.ac.uk \\ 2 Microbiology at Interfaces, Manchester Metropolitan University, Chester Street, Manchester M1 5GD, UK; \\ NATHALIE.KARAKY@stu.mmu.ac.uk \\ 3 Faculty of Science and Engineering, Manchester Metropolitan University, Chester Street, Manchester M1 5GD, \\ UK; gracescrowther@gmail.com (G.S.C.); Jonathan.Butler@mmu.ac.uk (J.A.B.); c.banks@mmu.ac.uk (C.E.B.) \\ 4 Division of Pharmacy and Optometry, Faculty of Biology, Medicine and Health, School of Health Sciences, \\ The University of Manchester, Manchester M13 9PL, UK; andrew.mcbain@manchester.ac.uk \\ * Correspondence: k.a.whitehead@mmu.ac.uk; Tel.: +44-(0)161-247-1157
}

check for

updates

Citation: Slate, A.J.; Karaky, N.; Crowther, G.S.; Butler, J.A.; Banks, C.E.; McBain, A.J.; Whitehead, K.A. Graphene Matrices as Carriers for Metal Ions against Antibiotic Susceptible and Resistant Bacterial Pathogens. Coatings 2021, 11, 352. https://doi.org/10.3390/ coatings 11030352

Academic Editor: Daniele Valerini

Received: 29 January 2021

Accepted: 16 March 2021

Published: 19 March 2021

Publisher's Note: MDPI stays neutral with regard to jurisdictional claims in published maps and institutional affiliations.

Copyright: (C) 2021 by the authors. Licensee MDPI, Basel, Switzerland. This article is an open access article distributed under the terms and conditions of the Creative Commons Attribution (CC BY) license (https:// creativecommons.org/licenses/by/ $4.0 /)$.

\begin{abstract}
Due to the ever-increasing burden of antimicrobial-resistant (AMR) bacteria, the development of novel antimicrobial agents and biomaterials to act as carriers and/or potentiate antimicrobial activity is essential. This study assessed the antimicrobial efficacy of the following ionic metals, silver, gold, palladium, platinum, zinc, and gallium alone and in combination with graphene matrices (which were coated via a drop casting coating method). The graphene foam was utilized as a carrier for the ionic metals against both, antibiotic susceptible and resistant bacterial strains of Acinetobacter baumannii, Staphylococcus aureus, Klebsiella pneumoniae and Pseudomonas aeruginosa. Ionic gold, palladium and platinum demonstrated the greatest antimicrobial activity against the susceptible and resistant strains. Scanning electron microscopy (SEM) visualized cellular ultrastructure damage, when the bacteria were incubated upon the graphene foam alone. This study suggests that specific metal ions applied in combination with graphene foam could present a potential therapeutic option to treat AMR bacterial infections. The application of the graphene foam as a potential carrier could promote antimicrobial activity, provide a sustained release approach and reduce possible resistance acquisition. In light of this study, the graphene foam and ionic metal combinations could potentially be further developed as part of a wound dressing.
\end{abstract}

Keywords: metal ions; graphene; antibiotic resistance; foams; biomaterials

\section{Introduction}

Healthcare-associated infections (HAIs) are a substantial burden on healthcare settings worldwide. The emergence of multidrug resistant (MDR) bacterial strains has further exacerbated this problem, resulting in serious financial burdens on healthcare services [1-3]. The lack of effective antimicrobial therapies to combat MDR bacterial strains has led to an urgent need to develop alternative therapeutic options [4].

It is estimated that in developed countries chronic wounds occur in around $2 \%$ of the population [5]. Delayed wound healing can lead to both local and systemic complications such as bacteraemia, osteomyelitis, sepsis and ultimately death [6]. Wound dressings play a pivotal role in the management of wound healing. The use of antimicrobial agents within the dressing structure, such as silver sulfadiazine, has been previously associated with a positive outcome, resulting in a reduction in bacterial infections [7]. Other wound dressings such as those which incorporate silver nanoparticles can also promote cellular proliferation and therefore wound healing, whilst maintaining high levels of antimicrobial efficacy [8,9].

Modern examples of metals utilised as therapeutic agents include cisplatin-based anti-cancer drugs, anti-arthritis drugs and topical antimicrobials (such as zinc salts) [10]. 
Different metal-based compounds have distinct structural configurations (e.g., ions, oxides and nanoparticles) which exhibit different mechanisms of antimicrobial action. The most common mechanisms of action however include, cellular ultrastructure damage via oxidative stress, membrane damage and protein dysfunction. Importantly, the application of metals as antimicrobial agents may result in a reduced probability of resistance occurrence; in contrast to many antibiotics, metals target multiple components of the bacterial cell, simultaneously [11-13].

Graphene is defined as a two-dimensional (2D) monolayer lattice of $\mathrm{sp}^{2}$ hybridised carbon atoms [14-16]. Graphene has unique properties such as excellent thermal and electrical conductivity, permeability to gasses, excellent tensile strength and it can be readily chemically functionalized, such properties have resulted in a plethora of applications [17]. Since its discovery in 2004, graphene and its derivatives, have been the focus of numerous research groups for a myriad of applications including electrochemistry (e.g., electrodes, sensors and supercapacitors), drug delivery (graphene-based drug carriers), dental fillers, water/surface disinfection and antimicrobial activity [18-23].

Antimicrobial properties have been demonstrated by graphene and its derivatives [24]. Graphene is believed to perturb the bacterial cytoplasmic membrane, due to the insertion of sharp graphene edges, leading to the loss of membrane integrity, resulting in cell lysis and death [25]. Other proposed antimicrobial mechanisms of graphene include wrapping, oxidative stress (with and without reactive oxygen species (ROS) production), lipid bilayer extraction and interference of protein-protein interactions [19,22]. Wrapping by graphene occurs when the microorganism is surrounded by graphene and nutritional and physicochemical conditions are altered [26]. Previously, simulations have demonstrated that graphene sheets $>5.20 \mathrm{~nm}$ could partially wrap around a bacterial species, resulting in the inversion of the phospholipid bilayer whilst, graphene sheets $<5.20 \mathrm{~nm}$ could penetrate the cell membrane [27]. A recent study conducted in 2020 by Butler et al., revealed that graphene derivatives (graphite, graphene and graphene oxide) potentiated the activity of antibiotics (ciprofloxacin, chloramphenicol and piperacillin/tazobactam) against Enterococcus faecium, Klebsiella pneumoniae and Escherichia coli [28].

Due to the increasing prevalence of MDR pathogens and scarcity of novel effective antibiotics, there has been very few major classes of broad-spectrum antibiotics developed over the last 40 years [29]. However, teixobactin, which was first discovered in 2015 is an effective antimicrobial agent against $S$. aureus and Mycobacterium tuberculosis; this antibiotic inhibits cell wall synthesis by binding to a highly conserved motif of lipid II (a precursor of peptidoglycan) and lipid III (a precursor of cell wall teichoic acid) [30]. Whilst, recent research conducted by Picconi et al., (2020) may have discovered a new broadspectrum antibiotic class in the form of modified pyrrolobenzodiazepines with a C8-linked aliphatic heterocycle [31]. This novel broad-spectrum antibiotic class demonstrated potent antimicrobial activity against MDR Gram-negative bacteria [31]. Whilst the emergence of new broad-spectrum antibiotics is promising, alternative therapies antimicrobial therapies must also be considered in order to effectively treat MDR infections. The utilisation of metals and graphene-based compounds may be one potential avenue to explore in order to alleviate the burden placed on traditional therapeutic options. Furthermore, the use of metal ions in combination with graphene (in this instance graphene coated with ionic metals to act as a carrier) could potentially promote antimicrobial activity, therefore acting as an alternative wound dressing treatment.

This study aimed to investigate the antimicrobial activity of metal ions in combination with graphene foams via a drop cast coating method in order to determine the antimicrobial efficacy, whilst demonstrating the efficacy of the graphene foams as therapeutic carriers against a range of antibiotic susceptible and resistant bacteria. 


\section{Materials and Methods}

\subsection{Bacterial Strains}

Four susceptible bacterial isolates, Staphylococcus aureus strain NCTC 12973, Klebsiella pneumoniae strain NCTC 9633, Acinetobacter baumannii strain NCTC 12156 and Pseudomonas aeruginosa strain NCTC 10332 and four resistant isolates, S. aureus hospital isolate 252, K. pneumoniae hospital isolate 1411061, A. baumannii isolate A483 and Pseudomonas aeruginosa strain VTK106689 were originally sourced from Leeds General Infirmary, UK. All strains were cultured on Tryptone Soya agar (TSA) or broth (TSB) and incubated for $24 \mathrm{~h}$ at $37^{\circ} \mathrm{C}$ unless stated otherwise. Before experimentation all strains were characterised for antibiotic resistance using both Gram-positive and Gram-negative/urine MASTRING-S ${ }^{\circledR}$ (Grampositive: M13/NCE, Gram-negative/Uropathogens M26/NCE, Mast Group, Merseyside, UK). Briefly, $100 \mu \mathrm{L}$ of bacterial suspension (optical density (OD) $1.0( \pm 0.1)$ at $540 \mathrm{~nm}$ ) was spread onto TSA and incubated at $37^{\circ} \mathrm{C}$ for $18 \mathrm{~h}$. The normalisation of the OD $540 \mathrm{~nm}$ resulted in bacterial concentrations of ca. $5.0 \times 10^{8} \mathrm{CFU} \mathrm{mL}^{-1}$. Negative controls (containing no bacteria) were included to confirm sterility (data not shown). Following incubation, zones of inhibition (ZoIs) were measured using digital calipers accurate to three decimal places, in order to determine antibiotic resistance profiles. Two bacterial isolates were included for each bacterial species, the bacterial strain that demonstrated the greatest ZoI for all relevant antibiotics (e.g., S. aureus and common Gram-positive antibiotics) was catergorised as susceptible, whilst the other was deemed resistant.

\subsection{Graphene Foam Preparation}

Three-dimensional multilayer graphene foam was procured from Graphene-Supermar ket, USA and sections were prepared using a sterile cork-borer ( $7 \mathrm{~mm}$ diameter) and then sterilised for $2 \mathrm{~h}$ under UV light at $375 \mathrm{~nm}$ prior to experimentation. A drop cast method was used to incorporate the metal ions into the graphene foam. Aliquots of $20 \mu \mathrm{L}$ of the test metal ion/acid (as described in the following section, "test compounds") were added directly to the surface of the graphene foam and left at room temperature for 30 min prior to experimentation.

\subsection{Test Compounds}

The metal ions evaluated in this study, silver, gold, palladium, platinum, zinc and gallium, were Atomic Absorption Standards (AAS) at a concentration of ca. $1000 \mu \mathrm{g} \mathrm{mL}^{-1}$ (1000 ppm) and were used without further modification (Merck, Feltham, UK). The solvents used to solubilise the metal ions were tested individually throughout this study and results were subtracted, in order to assure the antimicrobial effects observed were from the metal ions alone. Graphene foams (Graphene Supermarket, Reading, MA, USA) were also evaluated individually and in combination with the aforementioned metals.

\subsection{Disc Diffusion Assays}

The metal ions were evaluated individually and in combination with graphene foam (via a drop cast coating method) to determine their antimicrobial efficacy against the bacterial isolates. Bacterial strains were inoculated into TSB and incubated for $24 \mathrm{~h}$ at $37^{\circ} \mathrm{C}$ with agitation (150 rpm). Overnight cultures were then adjusted to an OD of $1.0( \pm 0.1)$ at $540 \mathrm{~nm}$. One hundred microliters of the adjusted suspension were inoculated onto a sterile TSA plate and spread to establish confluency. The graphene foams (pre-coated with metal ions) were then transferred to the centre of the inoculated agar plate. The antimicrobial activity of the metal solutions/acid controls in the absence of graphene was also evaluated by adding $20 \mu \mathrm{L}$ of each of the metal ion solutions onto a sterile filter paper (6 mm diameter), this was placed into the centre of the inoculated agar. All plates were incubated at $37^{\circ} \mathrm{C}$ for $24 \mathrm{~h}$ and zone of inhibition ( $\mathrm{ZoI})$ was established by measuring the inhibition diameter, using digital callipers accurate to $0.001 \mathrm{~mm}$. This experiment was performed in triplicate from three independent starting cultures. Note, that the ZoI of the metal solution was 
subtracted from the ZoI of its corresponding metal ion to account for any antimicrobial effect of the acid.

\subsection{Scanning Electron Microscopy}

Scanning electron microscopy (SEM) was used to visualise the bacterial cells postincubation with the graphene foam to determine if damage to the cellular ultrastructure was a potential mechanism of action. Following incubation upon silicon wafers or graphene foam $\left(24 \mathrm{~h}\right.$ at $\left.37^{\circ} \mathrm{C}\right)$, samples were dried at room temperature in a Class 2 biosafety cabinet (Atlas Clean Air, Preston, UK). The samples were prepared as per Butler et al. (2020) [32]. Briefly, the samples were fixed in $4 \% v / v$ glutaraldehyde for $24 \mathrm{~h}$ at $4{ }^{\circ} \mathrm{C}$. Once fixed the samples were rinsed with sterile deionized water and subjected to an ethanol gradient, $10 \%, 30 \%, 50 \%, 70 \%, 90 \%$ and $100 \% v / v$ absolute ethanol. The samples were then stored in a desiccator over $24 \mathrm{~h}$ to remove any moisture and were the sputter coated with gold for $30 \mathrm{~s}$ (Polaron, London, UK) using the following parameters (power $5 \mathrm{~mA}, 30 \mathrm{~s}, 800 \mathrm{~V}$, vacuum 0.09 mbar, argon gas). Scanning electron microscopy (SEM) was then performed using a JEOL (Tokyo, Japan) JSM-5600LV model SEM.

\subsection{Statistical Analysis}

Graphs were generated using Prism (Graphpad Software; version 8.4.3). The standard error of the mean (SEM) was denoted via error bars. For statistical analysis, $p$ values were calculated at the $95 \%$ confidence level by two-way ANOVAs, this was determined using Graphpad Prism (version 8). In all cases, $p<0.05$ was considered statistically significant. Asterisks denote significance, ${ }^{*} p \leq 0.05,{ }^{* *} p \leq 0.01,{ }^{* * *} p \leq 0.001$ and ${ }^{* * * *} p \leq 0.0001$.

\section{Results}

\subsection{Antibiotic Susceptibility Profiles}

The antibiotic susceptibility of the susceptible and resistant bacterial strains was determined against common broad-spectrum antibiotics that demonstrate antimicrobial activity against both Gram-positive (Figure 1A,B) and Gram-negative (Figure 2A,B) bacteria. When the antibiotics commonly utilised against Gram-positive bacteria were tested, $S$. aureus was the most susceptible strain, with eight out of eight antibiotics inhibiting the growth of this strain (NCTC 12973), whilst five out of the eight antibiotics (chloramphenicol, fusidic acid, novobiocin, streptomycin and tetracycline) resulted in growth inhibition of the resistant strain (Strain 252). The greatest inhibition of growth observed was by $10 \mu \mathrm{g}$ fusidic acid against the resistant strain (Strain 252), producing an average ZoI of $32.57 \mathrm{~mm}$. The least affected bacterial species to the commonly utilised antibiotics against Gram-positive bacteria was A. baumannii with only tetracycline producing a ZoI $(16.90 \mathrm{~mm})$ against the susceptible strain (NCTC 12156).

The MASTRING-S ${ }^{\circledR}$ antibiotics (M26/NCE) which are commonly utilised against urinary tract pathogens/Gram-negative bacteria were tested against the susceptible and resistant bacterial strains (Figure 2A,B). The growth of the susceptible strains, S. aureus (NCTC 12973) and K. pneumoniae (NCTC 9633) was the most affected with both exhibiting growth inhibition when tested against seven of the eight antibiotics. The largest ZoI $(26.80 \mathrm{~mm}$ ) was determined by $10 \mu \mathrm{g}$ tetracycline against the susceptible S. aureus strain. The resistant bacterial strains demonstrated greater resistance profiles; five out of the eight antibiotics inhibited S. aureus (Strain 252) growth, whilst three of the eight inhibited K. pneumoniae (Strain 1411061). The antibiotic which demonstrated the greatest growth inhibition observed was $10 \mu \mathrm{g}$ tetracycline $(31.30 \mathrm{~mm}$ ) produced against the resistant $S$. aureus (Strain 252). Overall, the most resistant strains utilised throughout this study were the resistant $A$. baumannii (LMDR A483) strain, with only two of the fourteen antibiotics inhibiting growth, and P. aeruginosa (VTK 106689) with only three antibiotics producing a ZoI. European Committee on Antimicrobial Susceptibility Testing (EUCAST) guidelines [33] were consulted to determine antimicrobial susceptibility (Electronic Supplementary Information, Table S1). 
A)

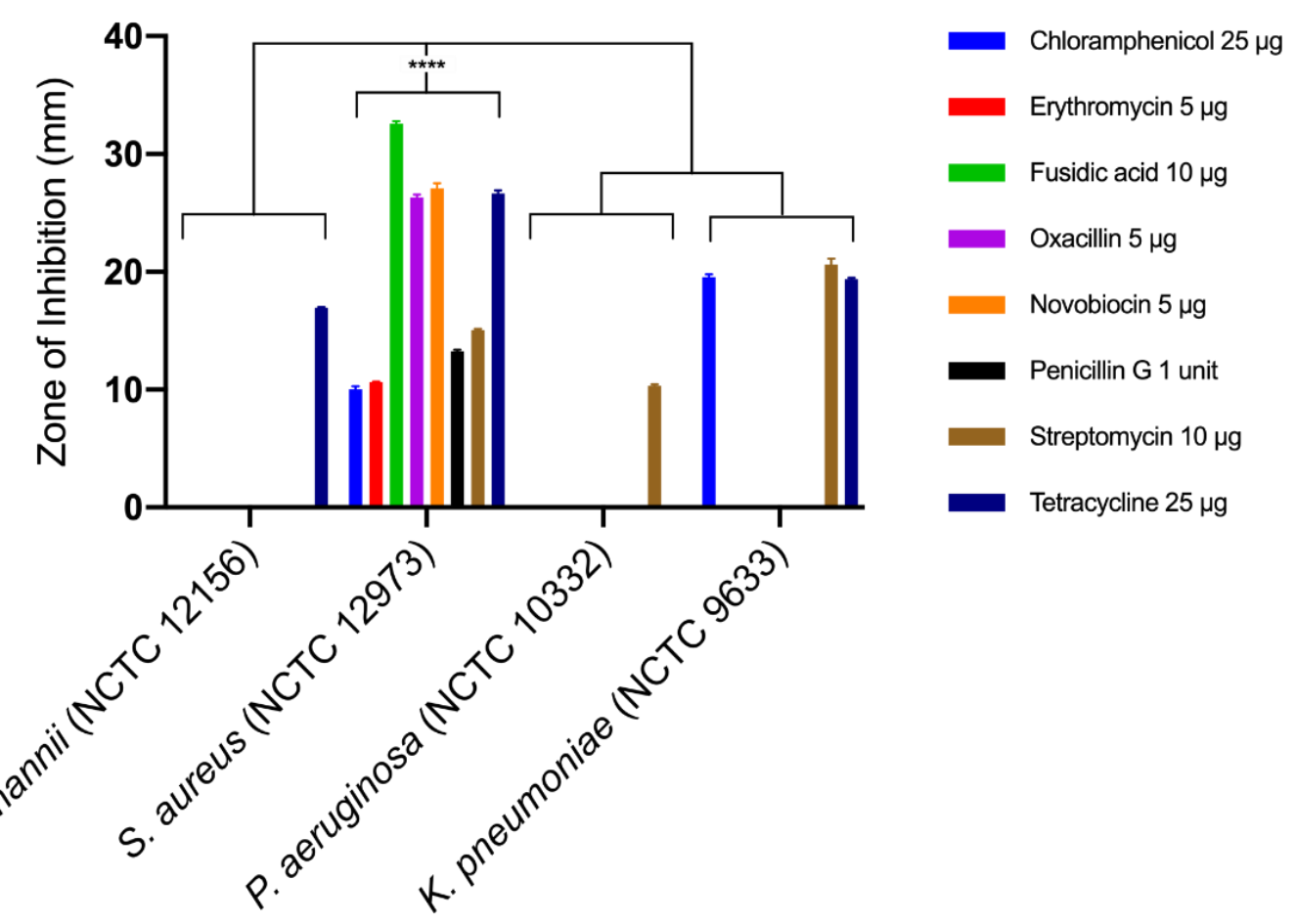

B)
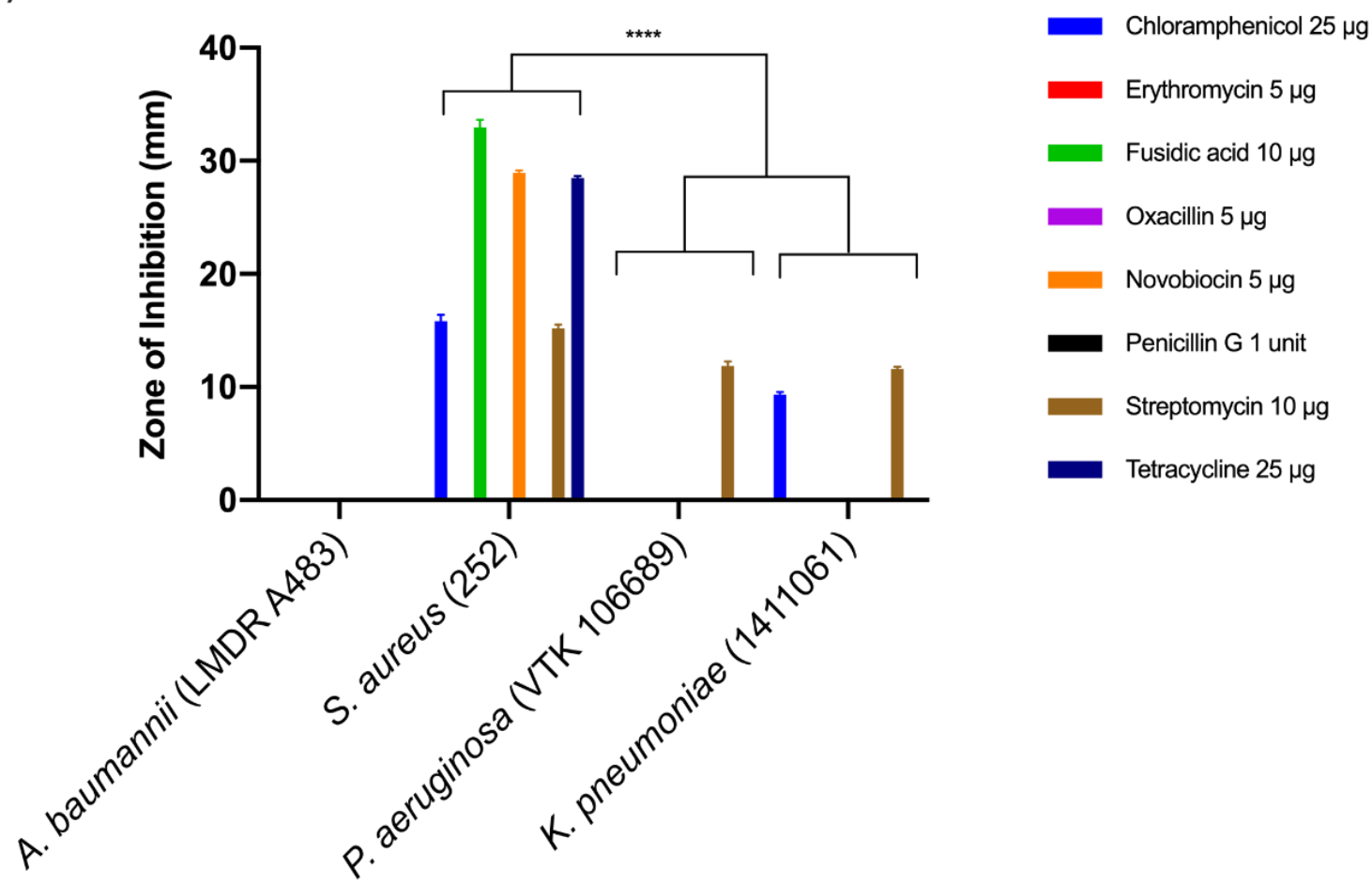

Figure 1. Antimicrobial susceptibility profiles against commonly used antibiotics against Gram-positive bacteria determined using MASTRING-S ${ }^{\circledR}$ (M13/NCE) against, (A) susceptible bacterial strains and $(\mathbf{B})$ resistant bacterial strains $(n=3)$ ***** $p \leq 0.0001$. 
A)

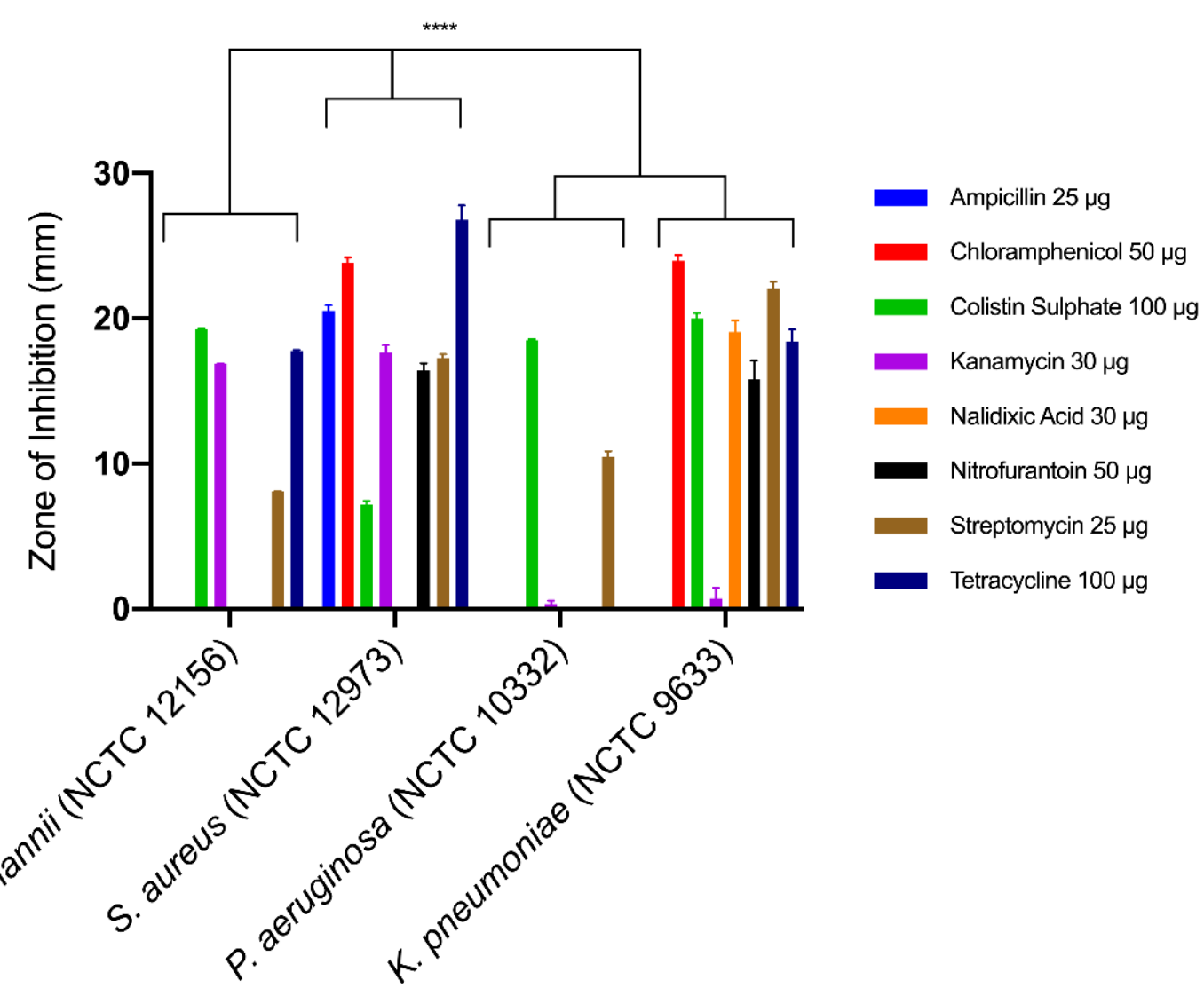

B)
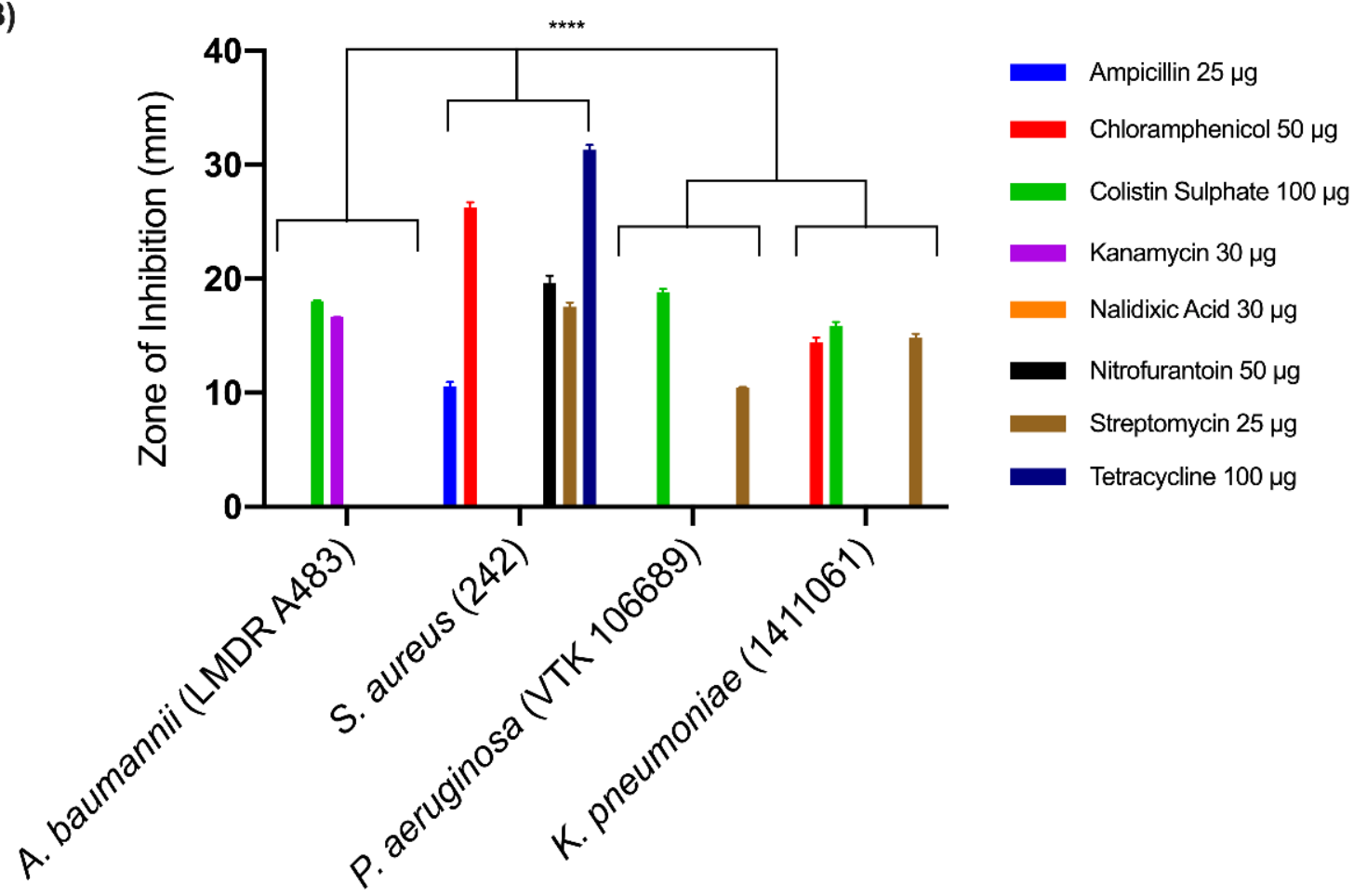

Figure 2. Antimicrobial susceptibility profiles against commonly used antibiotics against Gram-negative bacteria was determined using MASTRING-S ${ }^{\circledR}$ (M26/NCE) against, (A) susceptible bacterial strains and (B) resistant bacterial strains $(n=3)^{* * * *} p \leq 0.0001$. 


\subsection{Disc Diffusion Assays}

Metal Ions Alone and Graphene Alone

Overall, palladium and gold displayed the greatest antimicrobial efficacy against the eight susceptible and resistant isolates tested (Figure 3). Both metals were able to inhibit the growth of most of the isolates producing ZoIs in the range of 14.10-19.53 mm and $15.14-17.68 \mathrm{~mm}$ against the susceptible isolates, and $12.73 \mathrm{~mm}-14.21 \mathrm{~mm}$ and 12.17 $13.877 \mathrm{~mm}$ against the resistant strains, with palladium and gold, respectively. Silver, zinc and platinum similarly showed, good antimicrobial activity against the majority of the isolates (Figure 3A,B). The degree of antimicrobial activity by the metals tested observed was greater against the susceptible bacterial strains when compared to the resistant strains. Gallium exhibited the least antimicrobial activity of the metals tested against the bacterial isolates tested (Figure 3A,B). Interestingly, on average the metals produced greater inhibition of growth against the susceptible bacterial strains. Graphene exhibited the least antimicrobial activity producing ZoIs in the range of $7.00-7.78 \mathrm{~mm}$ for the susceptible strains and $7.82 \mathrm{~mm}-8.36 \mathrm{~mm}$ for the resistant strains.

A)
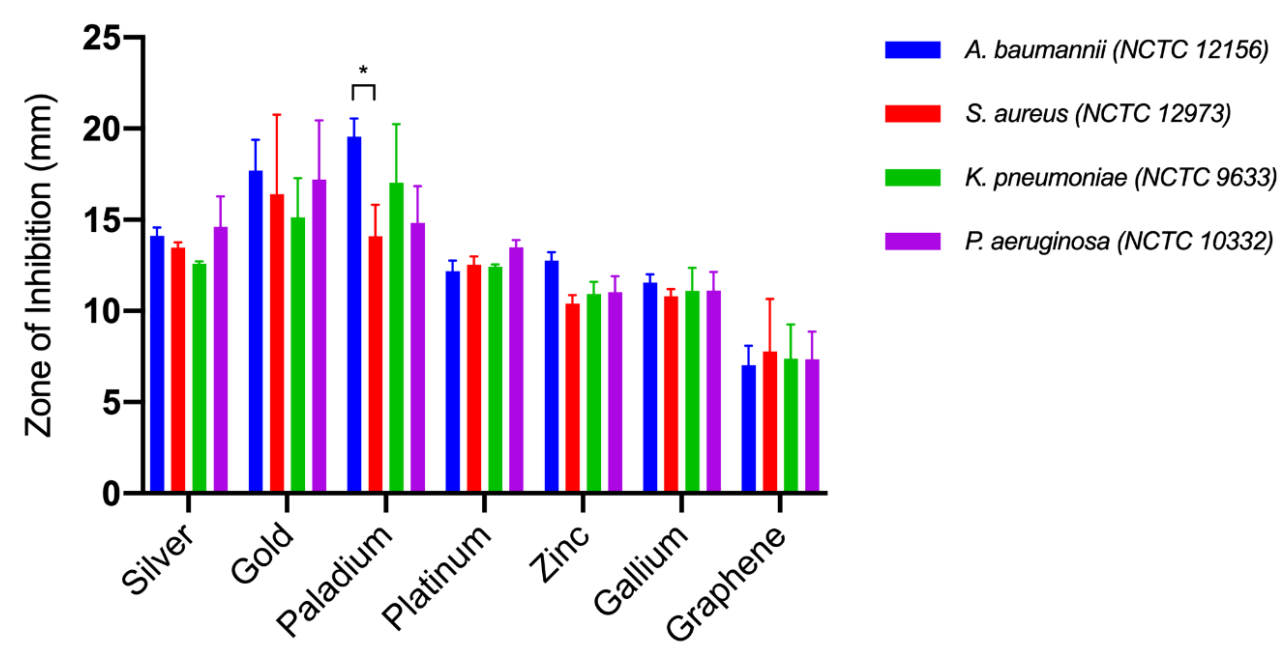

B)

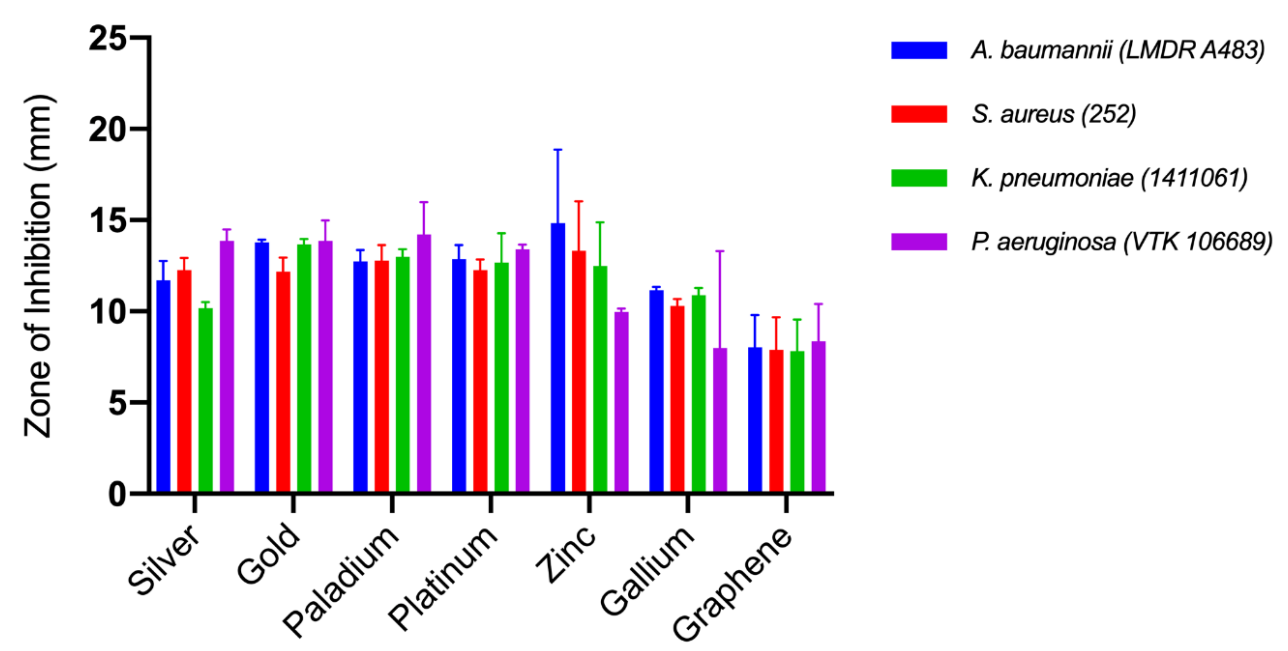

Figure 3. Zone of Inhibition determined by the metal ions and graphene alone against a range of (A) susceptible and (B) resistant bacteria $(n=3) * p \leq 0.05$. 


\subsection{Metal Ions and Graphene in combination with Graphene Foam}

To assess potentially synergistic activity of the metal ions when incorporated with graphene matrixes, zone of inhibition assays were conducted (Figure 4). In these assays, the graphene foam was used as a carrier for the metal ions. The antimicrobial efficacy demonstrated was similar to the metal ions tested alone, this indicated that the graphene did not have an antagonistic effect (Figure 3). Against the susceptible bacterial strains ionic silver in the presence of graphene demonstrated increased activity against $S$. aureus (14.60 mm; Figure 4A). Whilst, ionic platinum demonstrated slight synergistic activity with the graphene foams against the susceptible strains, producing enhanced ZoIs against $A$. baumannii $(14.17 \mathrm{~mm})$, K. pneumoniae $(13.88 \mathrm{~mm})$ and P. aeruginosa $(14.46 \mathrm{~mm})$ (Figure $4 \mathrm{~A})$.

A)

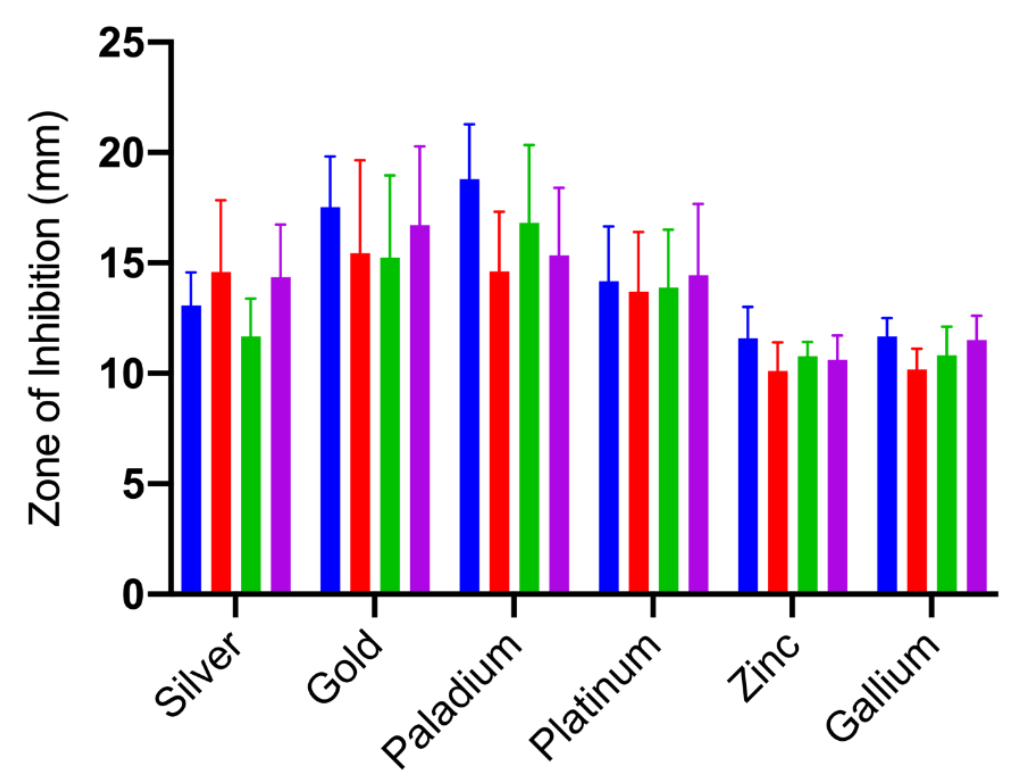

B)

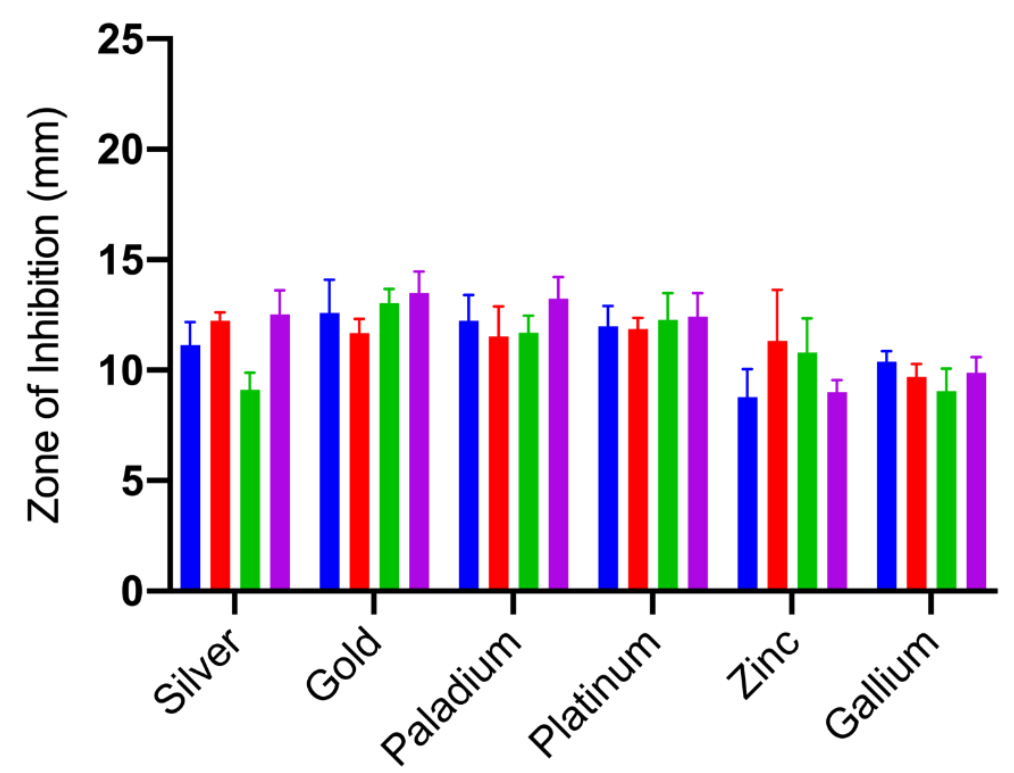

A. baumannii (NCTC 12156)

S. aureus (NCTC 12973)

K. pneumoniae (NCTC 9633)

P. aeruginosa (NCTC 10332)

A. baumannii (LMDR A483)

S. aureus (252)

P. aeruginosa (VTK 106689)

K. pneumoniae (1411061)

Figure 4. Zones of inhibition of graphene foams with metals on (A) antibiotic susceptible and (B) resistant bacteria $(n=3)$. 
The ZoI assays combining the metal ions with the graphene foam was then conducted with the resistant bacterial strains (Figure 4B). Overall, the addition of the metal ions to the graphene foams resulted in similar antimicrobial activity as observed by the metal ions alone, with no detriment to antimicrobial efficacy observed, against both the susceptible and resistant bacterial strains.

\subsection{Scanning Electron Microscopy}

To visualise the effect of the graphene foams on the cellular ultrastructure of the bacterial strains, SEM was conducted. Firstly, the structure of the graphene foam was visualised at a low $(\times 80)$ and higher magnification $(\times 5000)$ (Figure 5). At a lower magnification, a rough surface topography was observed with pits which were larger than single microbial cell dimensions, this indicates that the bacteria could become entrapped in the graphene structure.

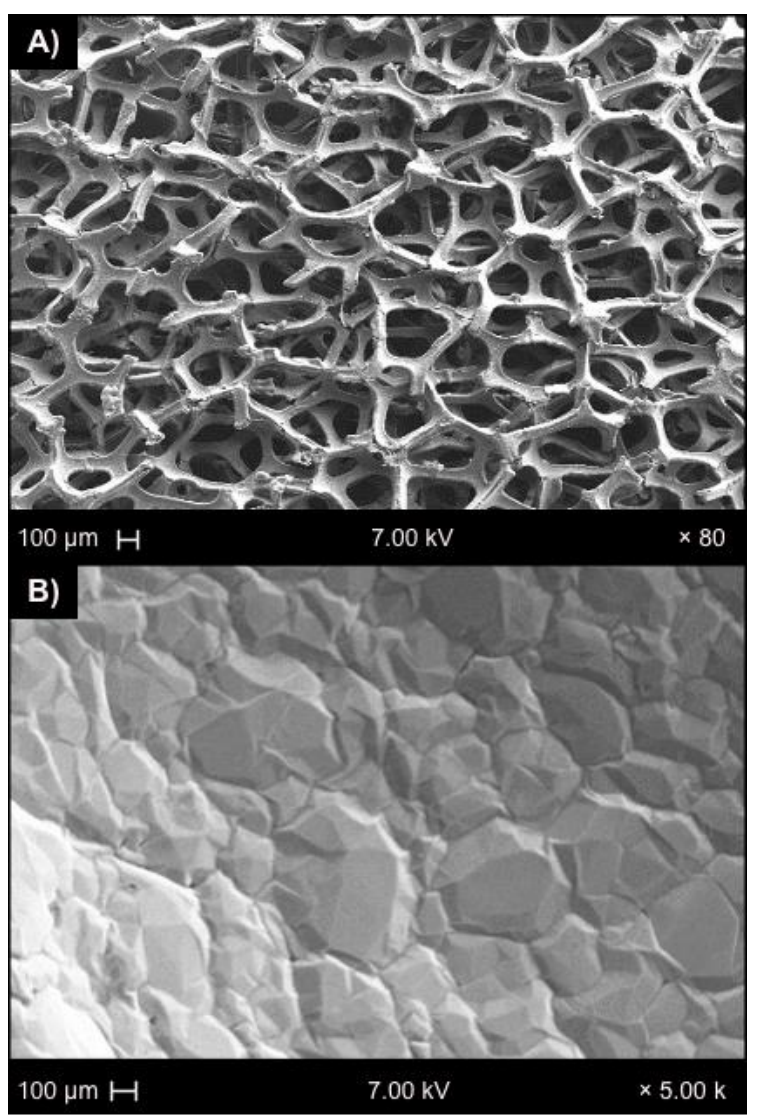

Figure 5. Scanning electron microscopy $($ SEM) images of $(\mathbf{A})$ low $(\times 80)$ and $(\mathbf{B})$ high $(\times 5000)$ magnification of graphene foam.

The bacterial strains were incubated for $24 \mathrm{~h}\left(\right.$ at $\left.37^{\circ} \mathrm{C}\right)$ on both silicon wafers and graphene foams, the morphology of the resistant bacterial cells was then visualised (Figure 6). The cells incubated on the silicon wafers were used as the control to effectively compare against S. aureus, K. pneumoniae, A. baumannii and P. aeruginosa (Figure 6A, $6 \mathrm{~B}, 6 \mathrm{C}$ and $6 \mathrm{D}$, respectively) incubated on the graphene foams. Following incubation on the graphene foam (Figure 6E), S. aureus was compared against the bacteria incubated on silicon wafers (Figure 6A), cellular debris was observed in the presence of the graphene foams (Figure 6F and 6G), whilst, some bacterial cells had developed pertusions through the cellular membrane (Figure 6E), which were not evident in the control bacterial sample. With the Gram-negative bacterial species, there was less of a pronounced effect observed, except for with the K. pneumoniae and A. baumannii cells (Figure 6F,G). When incubated on the graphene foams the $A$. baumannii cells are much smaller than the control which could 
indicate cellular leakage. The K. pneumoniae cells demonstrated a similar morphology to the $A$. baumannii cells when incubated on graphene foams (Figure 6F). The $P$. aeruginosa cells were largely unaffected by incubation with the graphene foams (Figure $6 \mathrm{H}$ ).

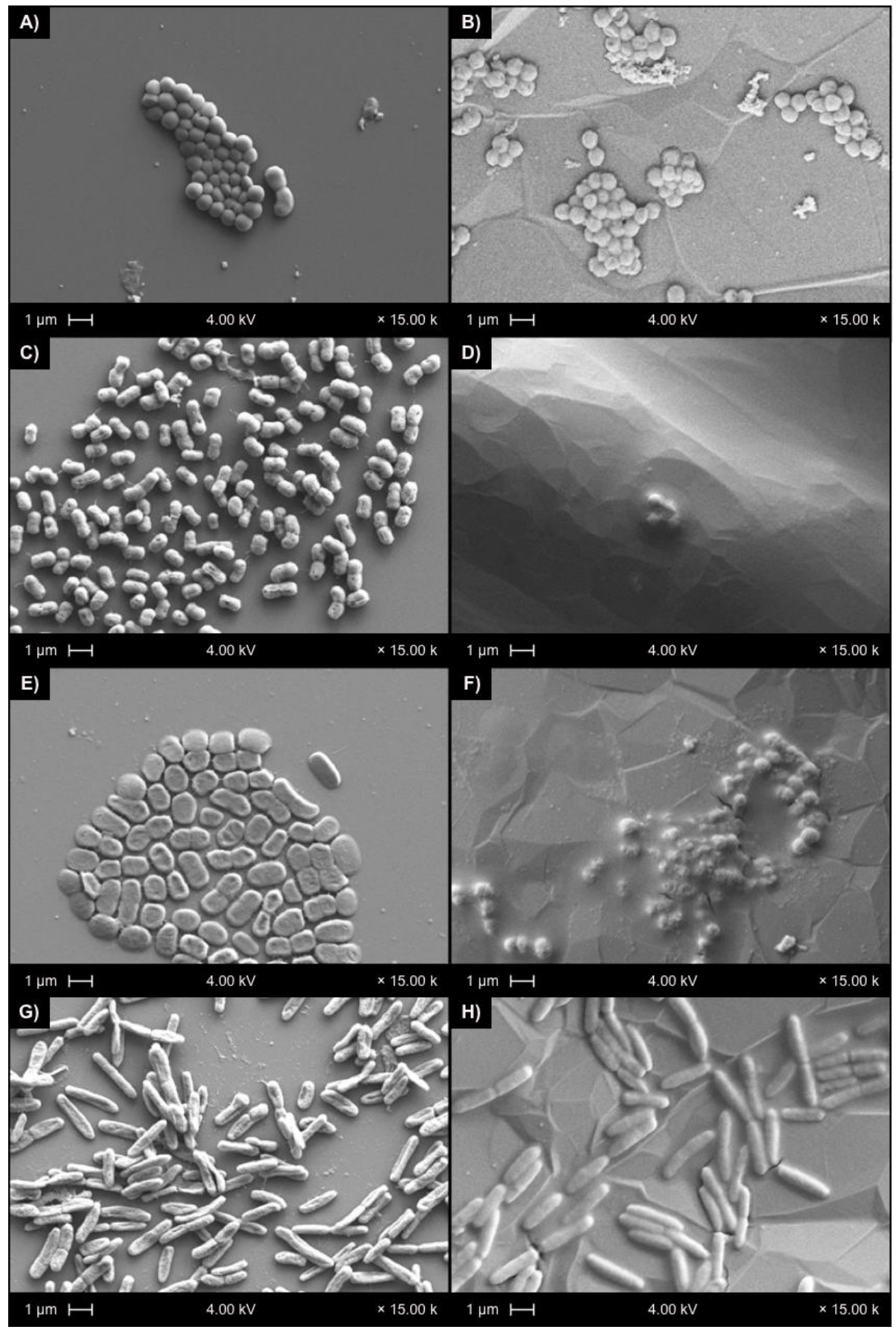

Figure 6. Comparison of the bacteria on (A-D) silicon and $(\mathrm{E}-\mathrm{H})$ graphene foam demonstrating the changes in the bacterial morphology against the resistant strains $(\mathbf{A}, \mathbf{E})$ S. aureus $(\mathbf{B}, \mathbf{F})$ K. pneumoniae (C,G) A. baumannii (D,H) P. aeruginosa. 


\section{Discussion}

The emergence of AMR has resulted in enhanced morbidity and mortality rates, which in turn results in longer hospital stays, thus placing a financial burden on healthcare services worldwide [34-36]. There is currently a lack of effective therapies to combat AMR infections [4], if this is not addressed it has been proposed that that by 2050, AMR infection will supersede cancer as the leading cause of mortality worldwide [37]. One potential avenue to be explored is the use of metal ions as alternative therapeutic options $[19,36,38,39]$. The utilization of graphene has grown rapidly in the last decade due to the unique properties of graphene and its derivatives, such materials have been widely explored for use as potential biomaterials [40-43]. Throughout this study, six metal ions, silver, gold, palladium, platinum, zinc and gallium were evaluated against susceptible and resistant bacterial strains, S. aureus, A. baumannii, K. pneumoniae and P. aeruginosa. Furthermore, the metal ions were tested individually and as part of a coated graphene combination to determine if this had an effect on the antimicrobial activity observed.

The bacterial strains were firstly evaluated in regard to their antibiotic resistance profiles and categorized as either susceptible or resistant in order to determine if the metal ions could be utilized to eradicate AMR bacterial strains. Antimicrobial resistant bacterial strains are becoming increasingly difficult to treat with some current treatment options become largely ineffective. In a previous study conducted by Vaidya et al., (2017), disc diffusion assays were conducted using silver, platinum, gold and palladium ions against K. pneumoniae strain NCTC 9633 and A. baumannii strain NCTC 12156 [44]. In contrast to the work presented in this previous study, the results in the current study showed some differences in antimicrobial efficacy, this may be due to the different growth media and conditions utilised $[44,45]$. However, unlike Vaidya et al., the current study incorporated ionic metals with graphene foam in order to determine if this potentiated the antimicrobial activity. When tested alone, gold and palladium ions produced the greatest growth inhibition, although when tested in combination with the graphene foam (where the graphene is coated with the metal ions via a drop cast method), silver and platinum ions were as effective as gold and palladium. The combination of graphene foam with palladium ions resulted in synergistic antimicrobial activity against the resistant bacterial strains.

The antimicrobial properties of metals have been used throughout medical history [46]. The use of metals as antimicrobial agents declined after the discovery of antibiotics. However, due to the emergence of AMR there is a lack of effective therapeutic options [47]. Therefore, there has been a revival in the application of metals as biocidal agents $[13,48]$. The antimicrobial action of metals begins with the affinity of metal ions towards cellular components and biomolecules, which form stable complexes and damage vital bacterial cell processes [49]. Metals demonstrate toxic effects in several ways, such as displacement/damage of essential enzymes, blocking vital biomolecule functional groups or participating in cellular chemical reactions [13]. One or more of these processes may damage proteins, denature DNA, induce oxidative stress or affect the biological walls/membranes [13]. Usually, metals demonstrate more than one antimicrobial mechanism of action, simultaneously. Such antimicrobial mechanisms include, generation of ROS, the depletion of antioxidants, the metal ions can also bind to the thiol groups of DNA, enzymes and proteins [13,50-52]; which results in cellular membrane damage, disruption of electron transport and inhibit nutrient acquisition - resulting in cell lysis and ultimately death [53,54].

The antimicrobial activity of graphene and its derivatives remains controversial and further research is required to elucidate the antimicrobial mechanisms of action [23]. Previous studies suggest that the antimicrobial action of graphene extends to multi-drug resistant bacterial strains [38,55]. Karaky et al., (2020) previously determined that graphene (MIC: $125 \mu \mathrm{g} \mathrm{mL}^{-1}$ ) and graphene oxide (MIC: $>500 \mu \mathrm{g} \mathrm{mL}^{-1}$ ) procured from the same source (Graphene Supermarket, USA) demonstrated little antimicrobial activity against a range of $P$. aeruginosa hospital isolates [38]. In a previous study, the antimicrobial activity of graphene was visualized using SEM, the presence of graphene sheets resulted in the 
loss of cell wall integrity in E. coli cells, resulting in cell death [56]. In the current study, SEM analysis revealed similar cellular ultrastructure damage to S. aureus, K. pneumoniae and A. baumannii.

The graphene foam used throughout this study has previously been characterised by Brownson et al., 2013 [57]. Raman spectroscopy revealed two characteristic peaks at ca. 1581 and $2684 \mathrm{~cm}^{-1}$ which are due to the $G$ and $2 D\left(G^{\prime}\right)$ bands respectively; the highly symmetrical $2 \mathrm{D}$ band and the intensity ratio of the $\mathrm{G}$ to $2 \mathrm{D}$ band indicate that the surface is comprised of mono- to few-layer graphene sheets [57]. Furthermore, $\mathrm{X}$-ray photoelectron spectroscopy (XPS) revealed the graphene foam comprised $95 \%$ carbon and $5 \%$ oxygen, whilst contact angle measurements revealed that the graphene foams exhibited a value of $120^{\circ}$, which indicated quasi-super-hydrophobicity [57].

Ionic gold, palladium and platinum demonstrated the greatest antimicrobial activity against the susceptible and resistant strains. Ionic gold like ionic silver, has a broadspectrum of antimicrobial activity, reacting with carboxyl-, phosphate- and amino-groups, whilst also reducing the activity of lactate dehydrogenase $[58,59]$. The antimicrobial effect of platinum ions has been well documented since the discovery of cisplatin [ $\mathrm{Pt}(\mathrm{II})(\mathrm{NH} 3) 2 \mathrm{Cl} 2]$ by Barnett Rosenberg in 1965. Rosenburg et al., 1965 were interested in the effect of electromagnetic radiation on both bacterial and mammalian cells when E. coli was incubated in a growth chamber with a set of platinum electrodes (which were considered inert), the electrical field resulted in morphological changes to the E. coli [14,60-62]. Palladium ions $\left(\mathrm{Pd}^{2+}\right)$ can inhibit enzyme function in eukaryotic cells and are known to inhibit creatine kinase, succinate dehydrogenase and other essential enzymatic processes [63]. In 2014, it was determined that concentrations as low as ca. $10^{-9} \mathrm{M}$ of $\mathrm{Pd}^{2+}$ ions resulted in the inhibition of $S$. aureus growth after $24 \mathrm{~h}$ exposure [64]. The results presented in the current study suggests the utilization of graphene foam in combination with specific metal ions may have the potential to be used as part of a surface coating or wound dressing. Further research is required to potentially develop metal ion/graphene foam surface coatings, such as cytotoxic effects on mammalian cells and an enhanced understanding towards the precise mechanisms of action of metal ions. However, the use of metal ions/graphene foams in combination could reduce the risk of infection and the development of antimicrobial resistance generation $[13,65]$.

\section{Conclusions}

The antimicrobial activity of six metal ions, silver, gold, palladium, platinum, zinc and gallium were evaluated against susceptible and resistant bacterial strains, S. aureus, A. baumannii, K. pneumoniae and P. aeruginosa. Furthermore, the metal ions were tested individually and in the presence of graphene foam (the metals were impregnated into the graphene surface via a drop cast method) to determine if this potentiated the antimicrobial activity observed. Ionic gold, palladium and platinum demonstrated the greatest antimicrobial activity against the susceptible and resistant strains. The combination of graphene foam with palladium ions resulted in synergistic antimicrobial activity against the resistant bacterial strains. Scanning electron microscopy (SEM) showed damage to the cellular ultrastructure when the bacterial strains were incubated upon the graphene foam alone. This study suggests that specific metal ions used in combination with graphene foam against specific bacterial strains (with different antibiotic-resistant profiles), could present a potential synergistic therapeutic option to treat AMR bacteria. Such combinations could potentially be used in a multitude of applications for example, wound dressings or surface coatings, effectively reducing wound infection and the transmission of common healthcare-acquired infections (HAIs).

Supplementary Materials: The following are available online at https:/ / www.mdpi.com/2079-641 2/11/3/352/s1, Table S1: Clinical Breakpoints determined by disc diffusion assays, data obtained via The European Committee on Antimicrobial Susceptibility Testing (EUCAST) valid from 1 January 2021 [33]. Antibiotics not classified by EUCAST have been omitted from this table. Abbreviations: ND; not determined. 
Author Contributions: K.A.W. conceptualised the project. A.J.S., N.K., G.S.C. and J.A.B. were involved in data acquisition and analysis. C.E.B., A.J.M. and K.A.W. supervised the project and supplied the relevant materials. A.J.S. drafted the final manuscript. All authors have read and agreed to the published version of the manuscript.

Funding: This work was funded by a Health Research Accelerator Award courtesy of the University of Manchester.

Institutional Review Board Statement: Not applicable.

Informed Consent Statement: Not applicable.

Data Availability Statement: The datasets generated during the current study are available from the corresponding author on reasonable request.

Conflicts of Interest: The authors declare no conflict of interest.

\section{References}

1. Lowy, F.D. Antimicrobial resistance: The example of Staphylococcus aureus. J. Clin. Investig. 2003, 111, 1265-1273. [CrossRef] [PubMed]

2. Breathnach, A.S. Nosocomial infections and infection control. Medicine 2013, 41, 649-653. [CrossRef]

3. Bassetti, M.; Merelli, M.; Temperoni, C.; Astilean, A. New antibiotics for bad bugs: Where are we? Ann. Clin. Microbiol. Antimicrob. 2013, 12, 22. [CrossRef]

4. Ventola, C.L. The antibiotic resistance crisis: Part 1: Causes and threats. Pharm. Ther. 2015, 40, $277-283$.

5. Gottrup, F. A specialized wound-healing center concept: Importance of a multidisciplinary department structure and surgical treatment facilities in the treatment of chronic wounds. Am. J. Surg. 2004, 187, S38-S43. [CrossRef]

6. Sydnor, E.R.M.; Perl, T.M. Hospital Epidemiology and Infection Control in Acute-Care Settings. Clin. Microbiol. Rev. 2011, 24, 141-173. [CrossRef]

7. Church, D.; Elsayed, S.; Reid, O.; Winston, B.; Lindsay, R. Burn Wound Infections. Clin. Microbiol. Rev. 2006, 19, 403-434. [CrossRef]

8. Liu, X.; Lee, P.-Y.; Ho, C.-M.; Lui, V.C.H.; Chen, Y.; Che, C.-M.; Tam, P.K.H.; Wong, K.K.Y. Silver Nanoparticles Mediate Differential Responses in Keratinocytes and Fibroblasts during Skin Wound Healing. ChemMedChem 2010, 5, 468-475. [CrossRef]

9. Lu, L.-C.; Chen-Wen, L.; Qing, W.; Min, H.; San-Jun, S.; Zi-Wei, L.; Guo-Lin, W.; Huan-Huan, C.; Yuan-Yuan, L.; Qian, Z.; et al. Silver nanoparticles/chitosan oligosaccharide/poly(vinyl alcohol) nanofiber promotes wound healing by activating TGF $31 /$ Smad signaling pathway. Int. J. Nanomed. 2016, 11, 373-387. [CrossRef] [PubMed]

10. McQuitty, R.J. Metal-based Drugs. Sci. Prog. 2014, 97, 1-19. [CrossRef] [PubMed]

11. Southam, H.M.; Butler, J.A.; Chapman, J.A.; Poole, R.K. The Microbiology of Ruthenium Complexes. In Advances in Microbial Physiology; Elsevier: Amsterdam, The Netherlands, 2017; Volume 71, pp. 1-96. [CrossRef]

12. Zhou, Y.; Kong, Y.; Kundu, S.; Cirillo, J.D.; Liang, H. Antibacterial activities of gold and silver nanoparticles against Escherichia coli and bacillus Calmette-Guérin. J. Nanobiotechnol. 2012, 10, 19. [CrossRef] [PubMed]

13. Lemire, J.A.; Harrison, J.J.; Turner, R.J. Antimicrobial activity of metals: Mechanisms, molecular targets and applications. Nat. Rev. Genet. 2013, 11, 371-384. [CrossRef]

14. Slate, A.J.; Whitehead, K.A.; Brownson, D.A.; Banks, C.E. Microbial fuel cells: An overview of current technology. Renew. Sustain. Energy Rev. 2019, 101, 60-81. [CrossRef]

15. Bianco, A.; Cheng, H.-M.; Enoki, T.; Gogotsi, Y.; Hurt, R.H.; Koratkar, N.; Kyotani, T.; Monthioux, M.; Park, C.R.; Tascon, J.M.; et al. All in the graphene family-A recommended nomenclature for two-dimensional carbon materials. Carbon 2013, 65, 1-6. [CrossRef]

16. Novoselov, K.S.; Geim, A.K.; Morozov, S.V.; Jiang, D.; Zhang, Y.; Dubonos, S.V.; Grigorieva, I.V.; Firsov, A.A. Electric Field Effect in Atomically Thin Carbon Films. Science 2004, 306, 666-669. [CrossRef] [PubMed]

17. Novoselov, K.S.; Fal'ko, V.I.; Colombo, L.; Gellert, P.R.; Schwab, M.G.; Kim, K. A roadmap for graphene. Nature 2012, 490, 192-200. [CrossRef]

18. Shao, Y.; Wang, J.; Wu, H.; Liu, J.; Aksay, I.A.; Lin, Y. Graphene Based Electrochemical Sensors and Biosensors: A Review. Electroanalysis 2010, 22, 1027-1036. [CrossRef]

19. Slate, A.; Karaky, N.; Whitehead, K.A. Antimicrobial properties of Modified Graphene and other advanced 2D Material Coated Surfaces. In 2D Materials_Characterization, Production and Applications; Banks, C.E., Brownson, D.A.C., Eds.; CRC Press: Boca Raton, FL, USA, 2018; pp. 86-104. [CrossRef]

20. Choi, W.; Lahiri, I.; Seelaboyina, R.; Kang, Y.S. Synthesis of Graphene and Its Applications: A Review. Crit. Rev. Solid State Mater. Sci. 2010, 35, 52-71. [CrossRef]

21. Liu, J.; Cui, L.; Losic, D. Graphene and graphene oxide as new nanocarriers for drug delivery applications. Acta Biomater. 2013, 9 , 9243-9257. [CrossRef] 
22. Zou, X.; Zhang, L.; Wang, Z.; Luo, Y. Mechanisms of the Antimicrobial Activities of Graphene Materials. J. Am. Chem. Soc. 2016, 138, 2064-2077. [CrossRef]

23. Hegab, H.M.; Elmekawy, A.; Zou, L.; Mulcahy, D.; Saint, C.P.; Ginic-Markovic, M. The controversial antibacterial activity of graphene-based materials. Carbon 2016, 105, 362-376. [CrossRef]

24. Chen, J.; Peng, H.; Wang, X.; Shao, F.; Yuan, Z.; Han, H. Graphene oxide exhibits broad-spectrum antimicrobial activity against bacterial phytopathogens and fungal conidia by intertwining and membrane perturbation. Nanoscale 2014, 6, 1879-1889. [CrossRef]

25. Akhavan, O.; Ghaderi, E. Toxicity of Graphene and Graphene Oxide Nanowalls Against Bacteria. ACS Nano 2010, 4, 5731-5736. [CrossRef] [PubMed]

26. Carpio, I.E.M.; Santos, C.M.; Wei, X.; Rodrigues, D.F. Toxicity of a polymer-graphene oxide composite against bacterial planktonic cells, biofilms, and mammalian cells. Nanoscale 2012, 4, 4746-4756. [CrossRef] [PubMed]

27. Dallavalle, M.; Calvaresi, M.; Bottoni, A.; Melle-Franco, M.; Zerbetto, F. Graphene Can Wreak Havoc with Cell Membranes. ACS Appl. Mater. Interfaces 2015, 7, 4406-4414. [CrossRef] [PubMed]

28. Butler, J.A.; Osborne, L.; El Mohtadi, M.; Whitehead, K.A. Graphene derivatives potentiate the activity of antibiotics against Enterococcus faecium, Klebsiella pneumoniae and Escherichia coli. AIMS Environ. Sci. 2020, 7, 106-113. [CrossRef]

29. Gill, E.E.; Franco, O.L.; Hancock, R.E.W. Antibiotic Adjuvants: Diverse Strategies for Controlling Drug-Resistant Pathogens. Chem. Biol. Drug Des. 2014, 85, 56-78. [CrossRef]

30. Ling, L.L.; Schneider, T.; Peoples, A.J.; Spoering, A.L.; Engels, I.; Conlon, B.P.; Mueller, A.; Schäberle, T.F.; Hughes, D.E.; Epstein, S.S.; et al. A new antibiotic kills pathogens without detectable resistance. Nature 2015, 517, 455-459. [CrossRef]

31. Picconi, P.; Hind, C.K.; Nahar, K.S.; Jamshidi, S.; Di Maggio, L.; Saeed, N.; Evans, B.; Solomons, J.; Wand, M.E.; Sutton, J.M.; et al. New Broad-Spectrum Antibiotics Containing a Pyrrolobenzodiazepine Ring with Activity against Multidrug-Resistant Gram-Negative Bacteria. J. Med. Chem. 2020, 63, 6941-6958. [CrossRef] [PubMed]

32. Butler, J.A.; Slate, A.J.; Todd, D.B.; Airton, D.; Hardman, M.; Hickey, N.A.; Scott, K.; Venkatraman, P.D. A traditional Ugandan Ficus natalensis bark cloth exhibits antimicrobial activity against methicillin-resistant Staphylococcus aureus. J. Appl. Microbiol. 2020. [CrossRef]

33. The European Committee on Antimicrobial Susceptibility Testing. Breakpoint Tables for Interpretation of MICs and Zone Diameters, Version 11.0. 2021. Available online: https:/ / eucast.org/clinical_breakpoints/ (accessed on 29 January 2021).

34. Llor, C.; Bjerrum, L. Antimicrobial resistance: Risk associated with antibiotic overuse and initiatives to reduce the problem. Ther. Adv. Drug Saf. 2014, 5, 229-241. [CrossRef]

35. Blair, J.M.A.; Webber, M.A.; Baylay, A.J.; Ogbolu, D.O.; Piddock, L.J.V. Molecular mechanisms of antibiotic resistance. Nat. Rev. Genet. 2014, 13, 42-51. [CrossRef]

36. Slate, A.J.; Shalamanova, L.; Akhidime, I.D.; Whitehead, K.A. Rhenium and yttrium ions as antimicrobial agents against multidrug resistant Klebsiella pneumoniae and Acinetobacter baumannii biofilms. Lett. Appl. Microbiol. 2019, 69, 168-174. [CrossRef] [PubMed]

37. O'Neill, J. Tackling Drug-Resistant Infections Globally: Final Report and Recommendations; HM Government and Welcome Trust: London, UK, 2016.

38. Karaky, N.; Kirby, A.; McBain, A.J.; Butler, J.A.; El Mohtadi, M.; Banks, C.E.; Whitehead, K.A. Metal ions and graphene-based compounds as alternative treatment options for burn wounds infected by antibiotic-resistant Pseudomonas aeruginosa. Arch. Microbiol. 2020, 202, 995-1004. [CrossRef] [PubMed]

39. Wahid, F.; Zhong, C.; Wang, H.-S.; Hu, X.-H.; Chu, L.-Q. Recent Advances in Antimicrobial Hydrogels Containing Metal Ions and Metals/Metal Oxide Nanoparticles. Polymers 2017, 9, 636. [CrossRef] [PubMed]

40. Ege, D.; Kamali, A.R.; Boccaccini, A.R. Graphene Oxide/Polymer-Based Biomaterials. Adv. Eng. Mater. 2017, 19. [CrossRef]

41. Feng, L.; Liu, Z. Graphene in biomedicine: Opportunities and challenges. Nanomedicine 2011, 6, 317-324. [CrossRef]

42. Han, S.; Sun, J.; He, S.; Tang, M.; Chai, R. The application of graphene-based biomaterials in biomedicine. Am. J. Transl. Res. 2019, 11,3246-3260. [PubMed]

43. Reddy, S.; Xu, X.; Guo, T.; Zhu, R.; He, L.; Ramakrishana, S. Allotropic carbon (graphene oxide and reduced graphene oxide) based biomaterials for neural regeneration. Curr. Opin. Biomed. Eng. 2018, 6, 120-129. [CrossRef]

44. Vaidya, M.Y.; McBain, A.J.; Butler, J.A.; Banks, C.E.; Whitehead, K.A. Antimicrobial Efficacy and Synergy of Metal Ions against Enterococcus faecium, Klebsiella pneumoniae and Acinetobacter baumannii in Planktonic and Biofilm Phenotypes. Sci. Rep. 2017, 7, 1-9. [CrossRef]

45. Verran, J.; Redfern, J.; Smith, L.A.; Whitehead, K.A. A critical evaluation of sampling methods used for assessing microorganisms on surfaces. Food Bioprod. Process. 2010, 88, 335-340. [CrossRef]

46. Elsome, A.M.; Hamilton-Miller, J.M.T.; Brumfitt, W.; Noble, W.C. Antimicrobial activities in vitro and in vivo of transition element complexes containing gold(I) and osmium(VI). J. Antimicrob. Chemother. 1996, 37, 911-918. [CrossRef] [PubMed]

47. Gold, K.; Slay, B.; Knackstedt, M.; Gaharwar, A.K. Antimicrobial Activity of Metal and Metal-Oxide Based Nanoparticles. Adv. Ther. 2018, 1. [CrossRef]

48. Dizaj, S.M.; Lotfipour, F.; Barzegar-Jalali, M.; Zarrintan, M.H.; Adibkia, K. Antimicrobial activity of the metals and metal oxide nanoparticles. Mater. Sci. Eng. C 2014, 44, 278-284. [CrossRef]

49. Nies, D.H. Microbial heavy-metal resistance. Appl. Microbiol. Biotechnol. 1999, 51, 730-750. [CrossRef] [PubMed] 
50. Feng, Q.L.; Wu, J.; Chen, G.Q.; Cui, F.; Kim, T.; Kim, J. A mechanistic study of the antibacterial effect of silver ions on Escherichia coli and Staphylococcus aureus. J. Biomed. Mater. Res. 2000, 52, 662-668. [CrossRef]

51. Stiefel, P.; Schmidt-Emrich, S.; Maniura-Weber, K.; Ren, Q. Critical aspects of using bacterial cell viability assays with the fluorophores SYTO9 and propidium iodide. BMC Microbiol. 2015, 15, 36-39. [CrossRef]

52. Kim, J.S.; Kuk, E.; Yu, K.N.; Kim, J.-H.; Park, S.J.; Lee, H.J.; Kim, S.H.; Park, Y.K.; Park, Y.H.; Hwang, C.-Y.; et al. Antimicrobial effects of silver nanoparticles. Nanomed. Nanotechnol. Biol. Med. 2007, 3, 95-101. [CrossRef]

53. Sondi, I.; Salopek-Sondi, B. Silver nanoparticles as antimicrobial agent: A case study on E. coli as a model for Gram-negative bacteria. J. Colloid Interface Sci. 2004, 275, 177-182. [CrossRef] [PubMed]

54. Hobman, J.L.; Crossman, L.C. Bacterial antimicrobial metal ion resistance. J. Med. Microbiol. 2015, 64, 471-497. [CrossRef] [PubMed]

55. Shoeb, M.; Mobin, M.; Rauf, M.A.; Owais, M.; Naqvi, A.H. In Vitro and in Vivo Antimicrobial Evaluation of Graphene-Polyindole (Gr@PIn) Nanocomposite against Methicillin-Resistant Staphylococcus aureus Pathogen. ACS Omega 2018, 3, 9431-9440. [CrossRef] [PubMed]

56. Oh, H.G.; Lee, J.-Y.; Son, H.G.; Kim, D.H.; Park, S.-H.; Kim, C.M.; Jhee, K.-H.; Song, K.S. Antibacterial mechanisms of nanocrystalline diamond film and graphene sheet. Results Phys. 2019, 12, 2129-2135. [CrossRef]

57. Brownson, D.A.C.; Figueiredo-Filho, L.C.S.; Ji, X.; Gómez-Mingot, M.; Iniesta, J.; Fatibello-Filho, O.; Kampouris, D.K.; Banks, C.E. Freestanding three-dimensional graphene foam gives rise to beneficial electrochemical signatures within non-aqueous media. $J$. Mater. Chem. A 2013, 1, 5962-5972. [CrossRef]

58. Shareena Dasari, T.P.; Zhang, Y.; Yu, H. Antibacterial Activity and Cytotoxicity of Gold (I) and (III) Ions and Gold Nanoparticles. Biochem. Pharmacol. Open Access 2015, 4, 1-5. [CrossRef]

59. Jung, W.K.; Koo, H.C.; Kim, K.W.; Shin, S.; Kim, S.H.; Park, Y.H. Antibacterial Activity and Mechanism of Action of the Silver Ion in Staphylococcus aureus and Escherichia coli. Appl. Environ. Microbiol. 2008, 74, 2171-2178. [CrossRef]

60. Tylkowski, B.; Jastrząb, R.; Odani, A. Developments in platinum anticancer drugs. Phys. Sci. Rev. 2018, 3. [CrossRef]

61. Monneret, C. Platinum anticancer drugs. From serendipity to rational design. Ann. Pharm. Fr. 2011, 69, 286-295. [CrossRef]

62. Rosenberg, B.; Van Camp, L.; Krigas, T. Inhibition of Cell Division in Escherichia coli by Electrolysis Products from a Platinum Electrode. Nature 1965, 205, 698-699. [CrossRef]

63. Liu, T.Z.; Lee, S.D.; Bhatnagar, R.S. Toxicity of palladium. Toxicol. Lett. 1979, 4, 469-473. [CrossRef]

64. Adams, C.P.; Walker, K.A.; Obare, S.O.; Docherty, K.M. Size-Dependent Antimicrobial Effects of Novel Palladium Nanoparticles. PLoS ONE 2014, 9, e85981. [CrossRef] [PubMed]

65. Richtera, L.; Chudobova, D.; Cihalova, K.; Kremplova, M.; Milosavljevic, V.; Kopel, P.; Blazkova, I.; Hynek, D.; Adam, V.; Kizek, R. The Composites of Graphene Oxide with Metal or Semimetal Nanoparticles and Their Effect on Pathogenic Microorganisms. Materials 2015, 8, 2994-3011. [CrossRef] 